\title{
Penyuluhan Pemanfaatan Biopigmen Tanaman Untuk Meningkatkan Imunitas Tubuh pada Masyarakat Muara Fajar Pekanbaru
}

\author{
${\text { Hartini } \mathbf{H}^{{ }^{*}} \text {, Agnes Farianti Rezeki Sihombing }}^{2}$ \\ ${ }^{12}$ Akademi Kesehatan John Paul II Pekanbaru \\ *E-mail: hartini.h@akjp2.ac.id
}

\section{Article History: \\ Received: November 2021 \\ Revised: November 2021 \\ Accepted: November 2021 \\ Available online:Desember 2021}

Keywords: biopigmen, daya tahan tubuh, masyarakat
Abstract: Coronavirus Disease 19 (Covid-19) merupakan suatu penyakit yang disebabkan oleh virus SARS-CoV-2. Virus SARS-CoV-2 dapat ditularkan melalui batuk, bersin, dan percikan yang keluar saat berbicara (droplet). Penyebaran Covid-19 yang sangat cepat ke berbagai negara membuat WHO menyatakan Covid-19 sebagai pandemi. Pencegahan dan penanganan Covid-19 dapat dilakukan dengan protokol kesehatan, pengobatan yang tepat dan meningkatkan daya tahan tubuh mengacu pada panduan gizi seimbang pada masa pandemi Covid-19 yang dikeluarkan oleh Kementerian Kesehatan RI. Salah satu upaya meningkatkan daya tahan tubuh telah dilakukan melalui pemberian penyuluhan tentang manfaat biopigmen yang tinggi akan antioksidan di Muara Fajar Pekanbaru. Tahapan kegiatan pengabdian ini telah dilaksanakan dengan melakukan peninjauan lokasi pengabdian, koordinasi dengan pemangku jabatan, penyiapan sarana prasarana dan penyuluhan. Penyuluhan dilakukan dengan metode ceramah, diskusi dan tanya jawab. Secara keseluruhan, kegiatan pengabdian ini berhasil dilaksanakan mengacu pada hasil analisis kuesioner pengabdian. Berdasarkan hal tersebut, disimpulkan bahwa 
kegiatan pengabdian bermanfaat bagi masyarakat dan masyarakat mengharapkan kegiatan pengabdian dilakukan secara berkala (berkelanjutan).

\section{Pendahuluan}

Coronavirus Disease-2019 (Covid-19) merupakan penyakit dari corona virus jenis baru yang sebelumnya belum pernah diidentifikasi pada manusia. Covid-19 berbeda dengan Severe Acute Respiratory Syndrome Coronavirus (SARS-Cov) yang menyebabkan penyakit SARS. Covid-19 merupakan suatu penyakit yang disebabkan oleh virus SARS-CoV-2 (Bhandari et al., 2020). SARS-CoV-2 termasuk dalam famili virus coronaviridae yang menjadi penyebab infeksi saluran pernapasan. COVID-19 dapat ditularkan dari manusia ke manusia lain melalui droplet atau kontak langsung pada benda yang telah terkontaminasi. Hal ini yang menyebabkan Covid-19 dapat menyebar dalam waktu yang singkat (Yang et al., 2020) sehingga Covid-19 dengan cepat menyebar ke seluruh dunia. Penyebaran COVID-19 yang sangat cepat ke berbagai Negara membuat WHO menyatakan COVID-19 sebagai pandemi pada 11 Maret 2020 (WHO, 2020a). Kasus positif COVID-19 di Indonesia terdapat pertama kali pada 2 Maret 2020 (WHO, 2020b). Dalam waktu yang singkat, Covid-19 juga menyebar ke berbagai Provinsi yang ada di Indonesia termasuk Provinsi Riau.

Pemerintah telah melakukan langkah-langkah untuk mencegah dan menangani Covid-19 antara lain menetapkan Pedoman pencegahan dan pengendalian Coronavirus Diseases-2019 (Covid-19) yang tertuang dalam Keputusan Menteri Kesehatan Republik Indonesia Nomor Hk.01.07/Menkes/413/2020 (Kementrian Kesehatan Republik Indonesia, 2020) serta mengeluarkan panduan gizi seimbang pada masa pandemi Covid19 (Kemenkes RI, 2020). Meningkatkan daya tahan tubuh menjadi salah satu kunci agar tidak tertular virus Covid-19. Oleh sebab itu, masyarakat perlu meningkatkan konsumsi makanan yang mengandung zat gizi seperti zat warna (biopigmen) yang tinggi kandungan antioksidan.

Antioksidan merupakan senyawa yang dapat menghambat reaksi oksidasi, dengan cara mengikat radikal bebas dan molekul yang sangat reaktif (Karseno et al, 2013). Tubuh memerlukan substansi penting, yakni antioksidan 
yang dapat membantu melindungi tubuh dari serangan radikal bebas dengan meredam dampak negatif senyawa radikal bebas tersebut (Rahmawati et al., 2017). Jenis antioksidan terdiri dari dua, yaitu antioksidan alam dan antioksidan sintetik (Puspita, 2014). Antioksidan alami banyak terdapat pada tumbuh-tumbuhan, sayur-sayuran dan buah-buahan (Tiwari et al, 2011)

Pentingnya konsumsi biopigmen yang tinggi kandungan antioksidan perlu dibekali kepada masyarakat. Kegiatan pengabdian kepada masyarakat yang telah dilakukan berupa penyuluhan pemanfaatan biopigmen tanaman untuk meningkatkan imunitas tubuh di masyarakat daerah Muara Fajar Pekanbaru. Adapun tujuan dari kegiatan pengabdian ini yaitu memberikan pengetahuan kepada masyarakat tentang cara meningkatkan daya tahan tubuh dan menambah wawasan tentang manfaat biopigmen yang tinggi akan antioksidan untuk kesehatan masyarakat.

\section{Metode}

Metode kegiatan pengabdian kepada masyarakat Muara Fajar Kota Pekanbaru terdiri dari 3 tahapan yaitu (1) peninjauan lokasi pengabdian; (2) melakukan koordinasi dengan RT.001/RW.004 dalam hal waktu kegiatan penyuluhan dan protokol kesehatan untuk penyuluhan; (3) penyiapan sarana dan materi untuk penyuluhan; (4) pelaksanaan penyuluhan kepada masyarakat Muara Fajar.

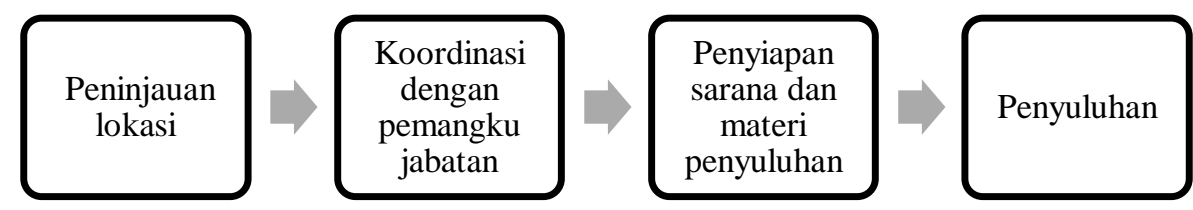

Gambar 1. Tahapan kegiatan pengabdian

Penyuluhan pemanfaatan biopigmen tanaman kepada masyarakat Muara Fajar terdiri dari 3 bagian yaitu:

1. Tahap pendahuluan

Pada tahap pendahuluan, tim pengabdian menyampaikan tentang institusi pengabdi yaitu Akademi Kesehatan John Paul II 
Pekanbaru, identitas tim pengabdi dan tujuan dari kegiatan pengabdian. Hal ini untuk mendekatkan diri dengan masyarakat yang menerima penyuluhan.

2. Tahap Penyuluhan

Tahap penyuluhan dilaksanakan dengan melakukan presentasi kepada masyarakat tentang biopigmen tanaman, jenis-jenis biopigmen dan manfaat biopigmen untuk meningkatkan imunitas tubuh. Pada tahap ini masyarakat diharapkan dapat memahami pentingnya manfaat dari biopigmen tanaman. Penyuluhan dilakukan dengan cara ceramah, tanya jawab/diskusi dan refleksi menyesuaikan dengan kondisi di lapangan.

3. Tahap evaluasi

Tahap tes akhir dilaksanakan untuk mengukur tingkat pengetahuan masyarakat. Tahap ini dilakukan dengan menyebar pertanyaan dalam bentuk kuesioner yang sederhana. Hasil dari tes akhir digunakan sebagai perbandingan ataupun penilaian objektif tentang pengetahuan masyarakat sebelum dan sesudah penyuluhan. Hasil analisisnya juga dapat digunakan pemangku jabatan untuk melakukan kebijakan dalam hal pemanfaatan tanaman disekitar lingkungan yang mengandung biopigmen.

\section{Hasil}

Kegiatan pengabdian kepada masyarakat diawali dengan melakukan peninjauan lokasi pengabdian di Muara Fajar kota Pekanbaru pada tanggal 7 Januari 2021. Pada tahapan peninjauan lokasi pengabdian menemukan bahwa masyarakat di Muara Fajar khususnya ibu-ibu umumnya sebagai Ibu Rumah Tangga (IRT). Tim selanjutnya melakukan koordinasi dengan pemangku jabatan yaitu RW dan RT di Muara Fajar. Bapak RT.001 dan RW.004 Muara Fajar sangat menyambut kedatangan Tim Pengabdian dan sangat terbuka untuk menerima kegiatan penyuluhan khususnya terkait penyuluhan peningkatan imunitas tubuh. Berdasarkan diskusi RT, RW dan Tim Pengabdian diperoleh kesepatan pelaksanaan kegiatan di 9 Februari 2021. 
Penyuluhan pemanfaatan biopigmen tanaman untuk meningkatkan imunitas tubuh pada masyarakat Muara Fajar Pekanbaru telah dilaksanakan pada 9 Februari 2021 bertempat di halaman rumah salah seorang warga. Jumlah masyarakat yang mengikuti kegiatan pengabdian sebanyak 38 orang. Kegiatan pengabdian dihadiri oleh RW.004, RT.001, masyarakat dan tim pengabdian. Pengabdian diawali dengan penyampaian gambaran singkat profil Akademi Kesehatan John Paul II Pekanbaru dan identitas dari tim pengabdian. Pada bagian pendahuluan, Bapak RT selaku pemangku jabatan juga menyampaikan agar masyarakat mengikuti kegiatan penyuluhan yang memanfaatkan biopigmen secara baik. Hal tersebut karena kegiatan penyuluhan di Muara Fajar baru pertama kali diadakan oleh Perguruan Tinggi bidang kesehatan.

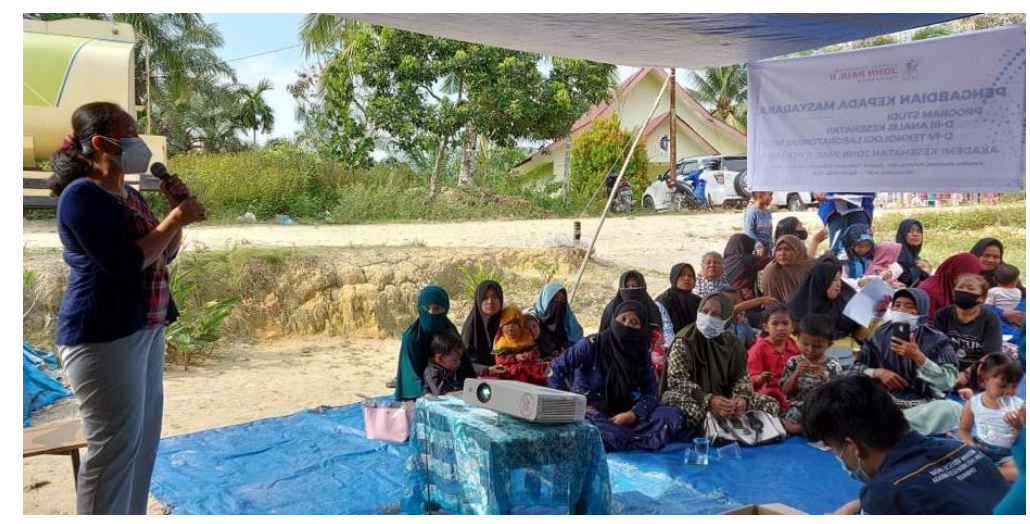

Gambar 2. Kegiatan penyuluhan

Kegiatan penyuluhan disajikan dalam bentuk presentasi. Presentasi berisi tentang pengertian biopigmen, jenis-jenis biopigmen, manfaat biopigmen dan tanaman yang menjadi sumber biopigmen (Gambar 2). Materi presentasi juga dilengkapi dengan gambar dan video yang memudahkan masyarakat dalam memahami materi yang disampaikan. Pada sesi penyuluhan, masyarakat diberikan waktu untuk tanya jawab dan berdiskusi. Masyarakat sangat antusias bertanya tentang cara pengolahan tanaman sehingga dapat memperoleh biopigmen untuk meningkatkan imunitas tubuh. Antusiasme masyarakat disampaikan secara lisan dan tulisan. Adapun 
penyampaian dalam tulisan, dilakukan dengan mengisi kuesioner pengabdian.

Tabel 1. Hasil analisis kuesioner kegiatan pengabdian

\begin{tabular}{|c|c|c|c|c|c|}
\hline \multirow{2}{*}{ No } & \multirow{2}{*}{ Pernyataan } & \multicolumn{4}{|c|}{ Jawaban (\%) } \\
\hline & & SS & $\mathbf{S}$ & TS & STS \\
\hline 1 & Materi PkM sesuai dengan kebutuhan masyarakat & 100 & 0 & 0 & 0 \\
\hline 2 & $\begin{array}{l}\text { Kegiatan PkM yang dilaksanakan sesuai dengan } \\
\text { harapan }\end{array}$ & 92,1 & 7,9 & 0 & 0 \\
\hline 3 & Cara pemateri menyajikan materi PkM menarik & 92,1 & 7,9 & 0 & 0 \\
\hline 4 & Materi yang disajikan jelas dan mudah dipahami & 94,7 & 5,3 & 0 & 0 \\
\hline 5 & $\begin{array}{l}\text { Waktu yang disediakan sesuai untuk } \\
\text { penyampaian materi dan kegiatan } \mathrm{PkM}\end{array}$ & 68,4 & 31,6 & 0 & 0 \\
\hline 6 & $\begin{array}{l}\text { Setiap keluhan/pertanyaan/permasalahan yang } \\
\text { diajukan ditindaklanjuti dengan baik oleh } \\
\text { narasumber pengabdian }\end{array}$ & 84,2 & 15,8 & 0 & 0 \\
\hline 7 & $\begin{array}{l}\text { Masyarakat mendapatkan manfaat langsung dari } \\
\text { kegiatan PkM yang dilaksanakan }\end{array}$ & 78,9 & 21,1 & 0 & 0 \\
\hline 8 & $\begin{array}{l}\text { Kegiatan PkM berhasil meningkatkan } \\
\text { pemahaman masyarakat khususnya tentang } \\
\text { biopigmen }\end{array}$ & 100 & 0 & 0 & 0 \\
\hline 9 & $\begin{array}{l}\text { Secara umum, masyarakat puas terhadap kegiatan } \\
\text { PkM }\end{array}$ & 100 & 0 & 0 & 0 \\
\hline 10 & $\begin{array}{l}\begin{array}{l}\text { Kegiatan PkM perlu dilakukan secara } \\
\text { berkelanjutan }\end{array} \\
\end{array}$ & 100 & 0 & 0 & 0 \\
\hline
\end{tabular}

Keterangan: SS= Sangat Setuju; S= Setuju; TS= Tidak Setuju; STS= Sangat Tidak Setuju

$\mathrm{PkM}=$ pengabdian kepada masyarakat

Pada akhir tahapan pengabdian seluruh masyarakat mengisi lembar evaluasi (kuesioner) dan dilanjutkan dengan analisis. Berdasarkan hasil analisis (Tabel 1) diperoleh bahwa masyarakat seluruhnya sangat setuju terhadap materi pengabdian, kegiatan pengabdian yang berhasil meningkatkan pemahaman masyarakat tentang biopigmen, puas terhadap kegiatan pengabdian dan kegiatan pengabdian perlu dilakukan secara berkelanjutan (respon kuesioner sebesar 100\%). Masyarakat juga menyampaikan bahwa 
kegiatan ini sangat menambah pengetahuan dan wawasan mereka terlebih di dalam kondisi pandemi.

\section{Kesimpulan}

Kegiatan pengabdian kepada masyarakat telah memberikan wawasan dan pengetahuan kepada masyarakat Muara Fajar Pekanbaru. Masyarakat dapat memahami tentang biopigmen, sumber biopigmen dan manfaatnya untuk meningkatkan imunitas tubuh. Berdasarkan kegiatan yang telah dilaksanakan diperoleh kesimpulan bahwa materi penyuluhan pemanfaatan biopigmen tanaman untuk meningkatkan imunitas tubuh pada masyarakat Muara Fajar Pekanbaru sesuai dengan kebutuhan masyarakat. Hal ini ditunjukkan dengan kemampuan masyarakat memahami materi pengabdian dan antusiasme masyarakat saat diskusi. Pada akhir kegiatan masyarakat juga menginginkan agar kegiatan pengabdian di Muara Fajar Pekanbaru dapat dilakukan secara berkelanjutan.

\section{Pengakuan/Acknowledgements}

Penulis mengucapkan terimakasih kepada Lembaga Penelitian dan Pengabdian kepada Masyarakat Akademi Kesehatan John Paul II Pekanbaru yang telah mendanai pengabdian ini melalui Dana Mandiri Yayasan John Paul II Pekanbaru dengan nomor 008/Perjanjian-Pengabdian/LPPM/AKJPII/2021. Penulis juga mengucapkan terimakasih kepada RW dan RT Muara Fajar Pekanbaru yang telah menjadi mitra dalam pengabdian ini.

\section{Daftar Referensi}

Bhandari, Shaktawat, A. S., Tak, A., Patel, B., Shukla, J., Singhal, S., Gupta, K., Gupta, J., Kakkar, S., \& Dube, A. (2020). Logistic regression analysis to predict mortality risk in COVID-19 patients from routine hematologic parameters. Ibnosina Journal of Medicine and Biomedical Sciences, 12(2), 123. https://doi.org/10.4103/ijmbs.

Kemenkes RI. (2020). Panduan Gizi Seimbang Pada Masa Covid-19. In Kementerian Kesehatan Republik Indonesia (p. 31).

Kementrian Kesehatan Republik Indonesia. (2020). Keputusan Menteri Kesehatan Republik Indonesia Nomor HK.01.07/MenKes/413/2020 Tentang Pedoman Pencegahan dan Pengendalian Corona Virus Disease 2019 (Covid-19). 
MenKes/413/2020, 2019, 207.

Karseno I. Handayani, Setyawati R. 2013. Aktivitas dan Stabilitas Antioksidan Ekstrak Pigmen Alga Oscillatoria sp. Jurnal Agritech Universitas Jenderal Soedirman. 33 (4): 371-376.

Tiwari, P., Kumar, B., Kaur, M., Kaur, G., Kaur, H. 2011. Phytochemical screening and Extraction: A Review. Internationale Pharmaceutica Sciencia 1(1): 98106Bhandari, Shaktawat, A. S., Tak, A., Patel, B., Shukla, J., Singhal, S., Gupta, K., Gupta, J., Kakkar, S., \& Dube, A. (2020). Logistic regression analysis to predict mortality risk in COVID-19 patients from routine hematologic parameters. Ibnosina Journal of Medicine and Biomedical Sciences, 12(2), 123. https://doi.org/10.4103/ijmbs.ijmbs

Kemenkes RI. (2020). Panduan Gizi Seimbang Pada Masa Covid-19. In Kementerian Kesehatan Republik Indonesia (p. 31).

Kementrian Kesehatan Republik Indonesia. (2020). Keputusan Menteri Kesehatan Republik Indonesia Nomor HK.01.07/MenKes/413/2020 Tentang Pedoman Pencegahan dan Pengendalian Corona Virus Disease 2019 (Covid-19). MenKes/413/2020, 2019, 207.

Puspita, M. (2014). Antibacterial and antioxidant properties of the red alga Gracilaria verrucosa from the. Indonesia Article in International Journal of Latest Research in Science and Technology, January. http://www.mnkjournals.com/ijlrst.htm

Rahmawati, Sinardi, \& Iryani, A. (2017). uji aktivitas antioksidan ekstrak etanol bunga brokoli (Brassica oleracea L. Var Italica) dengan metode DPPH (2,2difenil-1-1 pikrihidrazil). Prosiding Seminar Nasional Fakultas Teknik UNIFA, November, 230-241.

WHO. (2020a). Media Statement on confirmed COVID-19 cases.

WHO. (2020b). Virtual press conference on COVID-19 - 11 March 2020 (Issue March).

Yang, L., Liu, S., Liu, J., Zhang, Z., Wan, X., Huang, B., Chen, Y., \& Zhang, Y. (2020). COVID-19: Immunopathogenesis and Immunotherapeutics. Signal Transduction and Targeted Therapy, 5(128), 1-8. https://doi.org/10.1038/s41392-020-00243-2 